\title{
Detection of genotoxicity in hospital wastewater of a developing country using SOS chromotest and Ames fluctuation test
}

\author{
Roula M. Abdel-Massih ${ }^{1 *}$, Pamela N. Melki ${ }^{1}$, Claude Afif ${ }^{2}$ and Ziad Daoud ${ }^{2}$ \\ *Correspondence: roula.abdelmassih@balamand.edu.lb \\ 'Department of Biology, University of Balamand, Lebanon. \\ ${ }^{2}$ Faculty of Medicine and Medical Sciences, University of Balamand, Lebanon.
}

\begin{abstract}
Background: Hospitals discharge considerable amounts of chemicals in their wastewaters that may be genotoxic or present serious health hazards. The genotoxic potential of wastewater in a Lebanese University Hospital was evaluated using the SOS Chromotest and the Ames fluctuation test. Different concentrations were tested to determine the recommended dilution for each sample to decrease its genotoxicity.

Methods: The samples were taken from 5 different pits, 2 times per day in the morning and in the afternoon during two 1-week (5 days) periods in February and August 2011. SOS Chromotest and the Ames fluctuation were used to test genotoxicity.

Results and conclusions: This study revealed that hospital wastewater was mostly genotoxic. $50 \%$ of the samples were positive for genotoxicity in the SOS Chromotest and 67.5\% in the Ames fluctuation test. Genotoxicity of the sample was affected by the time, day, and season of sample collection. Different pits, representing different wastewater collection points, also varied with respect to the intensity of genotoxicity. Other genotoxic tests are currently underway to further evaluate the toxicity of these samples and to identify the genotoxic com pounds. This study shows that hospital wastewater must be carefully monitored and proper disposal or treatment measures need to be implemented.
\end{abstract}

Keywords: Genotoxicity, wastewater, SOS chromotest, ames fluctuation test

\section{Introduction}

Genotoxicity describes a deleterious action on a cell's genetic material affecting its integrity. Genotoxic and mutagenic effects are varied and often severe [1]. These effects may be related to mutagenesis, carcinogenesis, cell death, inhibition of cell division, DNA adducts, and chromosomal breakage [2]. Genotoxins can be mutagens, carcinogens and teratogens [3]. The genotoxicological effect related to the release of genotoxins in the environment has been a subject of interest in recent years. There is an increasing interest in the relationship between genotoxicity and carcinogenicity. More than 100 studies have used bioassays to investigate genotoxins in surface waters, sediments and industrial effluents [4-12].

Hospital wastewater may be considered as a reservoir of genotoxins and may be risky for humans and the environment due to the research activity/tests in its labs, release of chemicals, disinfectants, and excretion of drugs into wastewater [13-15]. If not treated properly, hospital effluents can damage the natural environment and create a biological imbalance by inducing hereditary defects, exhibiting teratogenic properties, inducing substantial reproductive loss in exposed populations [16-17] and influencing individual fitness by toxicity-related phenomena [1].
SOS Chromotest and Ames Fluctuation test were used in this study to assess genotoxicity. The SOS Chromotest was developed by Quillardet et al. [18]. It is a quantitative bacterial colorimetric assay for the detection of primary DNA damaging agents on a genetically engineered bacterium E. coli PQ37 [19]. The test employs a mutant strain of E. coli that detects induction of the SOS genes involved in DNA repair. E. coli PQ37 carries a sfiA::IacZ fusion. This tester strain has a deletion for the normal lac region and thus the $\beta$-galactosidase activity is strictly dependent on sfiA expression. The $\beta$-gal gene is responsible for the production of the $\beta$-galactosidase enzyme which is assayed in this test [20]. The strain was made constitutive for the alkaline phosphatase synthesis to verify if general protein synthesis is stable.

Whereas, the Ames fluctuation test is a liquid microplate version of the classical agar plate test; it is based on colorimetric readout [21-24]. The Ames test is used usually to evaluate the mutagenicity of pure chemicals and complex environmental mixtures [25]. This test uses Salmonella typhimurium strains that carry a mutant gene (His) which prevents the synthesis of the histidine from the ingredients of a normal bacterial culture medium. Salmonella TA98 strains have additional properties that increase their susceptibility to mutagens. In the presence

(C) 2013 Abdel-Massih et al; licensee Herbert Publications Ltd. This is an Open Access article distributed under the terms of Creative Commons Attribution License (http://creativecommons.org/licenses/by/3.0). This permits unrestricted use, distribution, and reproduction in any medium, provided the original work is properly cited. 
Table 1. Description of source of wastewater draining into different pits as described by hospital officials.

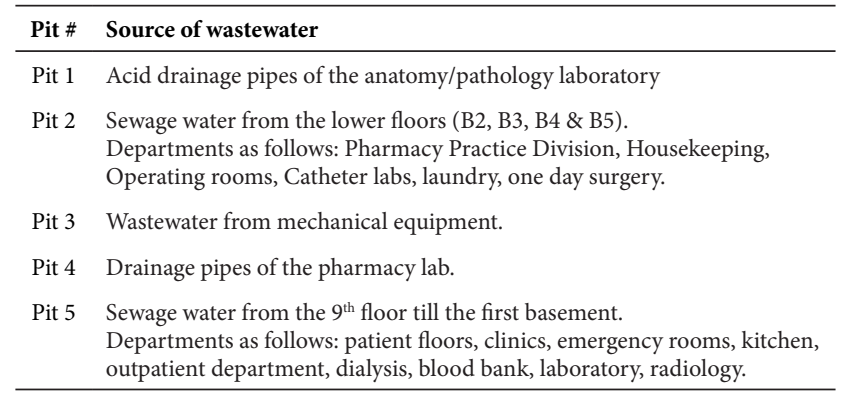

of a mutagen, the defective histidine gene will mutate back allowing revertants to grow in a standard medium. The histidine gene reverts back to the wild-type in TA98 strains due to frameshift mutations only. There are very few studies dealing with hospital wastewater toxicity in the Mediterranean area. According to our knowledge this is the first assessment on hospital wastewater genotoxicity in Lebanon. It is of major concern to study wastewater genotoxicity in developing countries especially that wastewater treatment plants are mostly absent and no real regulatory requirements are present. The University Hospital studied is considered to be one of the largest hospitals in the country with an average 10,000 to 15,000 admissions/year and an occupancy rate of 0.7 for the period of the study (2011). This hospital consists of 250 beds and is a referral center receiving patients from all over the country. In this study the SOS Chromotest and Ames fluctuation tests were used to detect possible genotoxic effects of effluents from a University Hospital in Lebanon.

\section{Materials and methods Test bacterial strains}

The two genetically engineered strains, Escherichia coli PQ37 and Salmonella typhimurium TA98 were kindly provided by Dr. Montserrat Llagostera Casas (Universitat Autònoma de Barcelona, Spain). They were stored at $-80^{\circ} \mathrm{C}$ and thawed before the assay.

\section{Sampling of hospital wastewater}

Two liters of wastewater were collected in High Density Polyethylene (HDPE) bottles at different time intervals from different pits. Pits consist of wastewater from different departments and floors in the hospital (Table 1). The samples were taken during the hospital maximal activity period, in the morning (9am-10am) and in the afternoon (4pm-5pm), over two 1-week (5days) periods in February and August 2011. The first collection was taken from 22 till $28^{\text {th }}$ of February and the second batch from 19 till $25^{\text {th }}$ of August. The samples were stored at $-20^{\circ} \mathrm{C}$ until tested. Samples were filtered with cellulose acetate filters $(0.45 \mathrm{~mm}$ pore size; Sartorius Minisart, Germany) before conducting the genotoxicity assays.

\section{SOS Chromotest}

The SOS Chromotest was performed without metabolic activation as described by Quillardet and Hofnung [2] with modifications [26]. Briefly, $600 \mu \mathrm{l}$ of E. coli PQ37 $\left(10^{8} \mathrm{cfu} /\right.$ $\mathrm{ml}$ ) culture was distributed into autoclaved glass tubes containing $20 \mu \mathrm{l}$ of samples with different concentrations. These mixtures were incubated for 2 hours at $37^{\circ} \mathrm{C}$ in a gyratory incubator. $\beta$-galactosidase and phosphatase alkaline activities were determined in these tubes using o-nitrophenyl- $\beta$ - $D$-galactopyranoside (ONPG) and p-nitrophenyl phosphate disodium substrate (PNPP) respectively. Absorption was studied at $420 \mathrm{~nm}$ using a reference solution with no bacteria. Different sampling pits required different amounts of solvents (Dimethyl sulfoxide (DMSO) or water) to dissolve.

Negative controls studied consisted of the solvent (distilled water or DMSO) with the culture medium; whereas 4-nitroquinoline 1-oxide (4NQO) was used as a positive control [27]. Samples $(20 \mu \mathrm{l})$ were tested at different concentrations: $x 2$ concentrated sample $(6.67 \%), x 1$ sample $(3.33 \%), 3 / 4^{\text {th }}$ sample $(2.5 \%), 1 / 2$ diluted sample $(1.67 \%)$, and $1 / 4^{\text {th }}$ sample $(0.83 \%)$; where the percentage represents the volume of the sample in the medium. The (x2) sample was concentrated by means of a Speedvac concentrator.

The enzymes units were calculated as described by Miller [28]:

Enzyme units $=1000^{*}$ A420/t.

A420 is the optical density at $420 \mathrm{~nm}$, and t is the time of incubation between the initiation and the termination of the assay [2]. The genotoxicity $R_{c}$ for a certain concentration is expressed as the ratio of the enzymes units of both enzymes ( $\beta$-galactosidase and phosphatase alkaline): $R_{c}=$ $\beta$-galactosidase units /alkaline phosphatase units.

To compare the results between experiments, the $R_{c}$ ratio should be normalized by dividing it by its value at concentration 0 of the sample. Thus, the induction factor (IF) is defined for a concentration c of the sample as $R_{c} / R_{o^{\prime}}$ where $R_{o}$ is the ratio measured with the solvent control (sterile distilled water or DMSO). To consider a sample as genotoxic or an SOS repair inducer, it should have an IF value of at least 1.5. The $\beta$-galactosidase activity should increase significantly compared to the negative control and genotoxicity should be dose-dependent. All the results are expressed as the mean of 3 experiments ( \pm standard deviation).

\section{Ames test}

The fluctuation test was performed as described by Legault et al., [29] and conducted without metabolic activation [30].The bacterial culture was prepared in Luria broth overnight at $37^{\circ} \mathrm{C}$ in a shaking incubator. The medium was prepared by adding Davis-Mingioli salts (5.5x), D-glucose (400 mg/ml), D-biotin $(0.1 \mathrm{mg} / \mathrm{ml})$, L-histidine $(1 \mathrm{mg} / \mathrm{ml})$, and 
Table 2. Hospital Wastewater Genotoxicity as tested by the SOS chromotest from the first batch collected (February 22-28, 2011) at different concentrations.

\begin{tabular}{|c|c|c|c|c|c|c|c|c|c|c|c|c|}
\hline \multicolumn{13}{|c|}{ Pit 1} \\
\hline \multirow[t]{2}{*}{ Day } & \multicolumn{5}{|c|}{ Morning Sample Concentration } & \multirow{2}{*}{$\begin{array}{c}\text { Genotoxicity } \\
-\end{array}$} & \multicolumn{5}{|c|}{ Afternoon Sample Concentration- } & Genotoxicity \\
\hline & $1 / 4$ & $1 / 2$ & $3 / 4$ & $\times 1$ & $\times 2$ & & $1 / 4$ & $1 / 2$ & $3 / 4$ & $\times 1$ & $\times 2$ & - \\
\hline Friday & 1.29 & 1.83 & 4.25 & 4.75 & 7.62 & + & 1.76 & 1.9 & 2.33 & 4.46 & 4.67 & + \\
\hline Monday & 2.51 & 2.59 & 3.00 & 3.05 & 3.73 & + & 2.76 & 3.33 & 3.50 & 4.68 & 5.58 & + \\
\hline Tuesday & 2.82 & 3.13 & 3.91 & 3.94 & 4.06 & + & 1.04 & 1.75 & 2.12 & 2.14 & 5.86 & + \\
\hline Wed. & 2.35 & 3.00 & 4.75 & 4.28 & 8.84 & + & 1.80 & 1.95 & 3.09 & 2.77 & 6.85 & + \\
\hline \multirow[t]{3}{*}{ Thursday } & 2.83 & 2.99 & 4.16 & 4.45 & 5.68 & + & 2.63 & 3.02 & 3.88 & 3.79 & 5.70 & + \\
\hline & \multicolumn{11}{|c|}{ Pit 2} & \\
\hline & $1 / 4$ & $1 / 2$ & $3 / 4$ & $\times 1$ & $\times 2$ & - & $1 / 4$ & $1 / 2$ & $3 / 4$ & $\times 1$ & $\times 2$ & - \\
\hline Friday & 1.03 & 1.03 & 1.38 & 1.38 & 1.75 & - & 0.81 & 0.82 & 0.96 & 1.06 & 1.25 & - \\
\hline Monday & 1.09 & 1.26 & 1.24 & 1.27 & 1.77 & - & 0.89 & 0.93 & 1.17 & 1.33 & 2.72 & - \\
\hline Tuesday & 1.07 & 1.00 & 0.97 & 1.52 & 1.90 & + & 1.17 & 1.6 & 1.62 & 1.41 & 2.13 & - \\
\hline Wed. & 0.74 & 0.78 & 0.79 & 0.91 & 1.50 & - & 0.75 & 1.02 & 1.61 & 1.34 & 0.58 & - \\
\hline \multirow[t]{3}{*}{ Thursday } & 0.93 & 1.13 & 2.05 & 2.09 & 1.47 & + & 0.85 & 0.97 & 1.03 & 1.26 & 0.96 & - \\
\hline & \multicolumn{11}{|c|}{ Pit 3} & \\
\hline & $1 / 4$ & $1 / 2$ & $3 / 4$ & $\times 1$ & $\times 2$ & - & $1 / 4$ & $1 / 2$ & $3 / 4$ & $\times 1$ & $\times 2$ & - \\
\hline Friday & 0.64 & 0.67 & 0.84 & 0.85 & 0.94 & - & 1.09 & 1.22 & 1.23 & 1.34 & 1.63 & - \\
\hline Monday & 1.37 & 1.46 & 1.52 & 1.5 & 1.52 & + & 1.73 & 1.84 & 1.86 & 1.92 & 1.96 & + \\
\hline Tuesday & 1.33 & 0.94 & 1.34 & 1.53 & 1.72 & + & 0.74 & 0.8 & 0.92 & 0.77 & 1.14 & - \\
\hline Wed. & 0.8 & 1.05 & 1.46 & 1.64 & 1.35 & + & 0.87 & 0.9 & 0.89 & 1.03 & 1.63 & - \\
\hline \multirow[t]{3}{*}{ Thursday } & 0.92 & 1.15 & 1.14 & 1.18 & 0.84 & - & 0.69 & 0.71 & 1.16 & 1.26 & 1.12 & - \\
\hline & \multicolumn{11}{|c|}{ Pit 4} & \\
\hline & $1 / 4$ & $1 / 2$ & $3 / 4$ & $\times 1$ & $\times 2$ & - & $1 / 4$ & $1 / 2$ & $3 / 4$ & $\times 1$ & $\times 2$ & - \\
\hline Friday & 1.2 & 1.53 & 1.55 & 1.65 & 1.47 & + & 1.14 & 1.18 & 1.27 & 1.29 & 1.34 & - \\
\hline Monday & 1.33 & 1.33 & 1.57 & 1.76 & 3.59 & + & 1.20 & 1.40 & 1.34 & 1.64 & 3.15 & + \\
\hline Tuesday & 0.84 & 0.99 & 0.90 & 0.98 & 1.79 & - & 0.88 & 0.96 & 1.11 & 1.01 & 1.44 & - \\
\hline Wed. & 0.96 & 1.01 & 1.52 & 1.56 & 1.06 & + & 0.95 & 1.04 & 1.04 & 1.04 & 1.07 & - \\
\hline \multirow[t]{3}{*}{ Thursday } & 0.9 & 1.08 & 1.24 & 1.27 & 1.48 & - & 0.99 & 1.04 & 1.06 & 1.21 & 1.36 & - \\
\hline & \multicolumn{11}{|c|}{ Pit 5} & \\
\hline & $1 / 4$ & $1 / 2$ & $3 / 4$ & $\times 1$ & $\times 2$ & - & $1 / 4$ & $1 / 2$ & $3 / 4$ & $\times 1$ & $\times 2$ & - \\
\hline Friday & 1.28 & 1.53 & 1.55 & 1.65 & 1.47 & + & 1.57 & 1.77 & 1.86 & 1.85 & 2.05 & + \\
\hline Monday & 1.82 & 1.89 & 1.87 & 1.96 & 2.06 & + & 2.89 & 2.96 & 3.00 & 3.02 & 3.10 & + \\
\hline Tuesday & 0.93 & 0.94 & 1.13 & 1.28 & 1.90 & - & 0.79 & 1.15 & 1.23 & 1.31 & 1.65 & - \\
\hline Wed. & 1.06 & 1.16 & 1.40 & 1.49 & 2.10 & - & 0.56 & 0.67 & 0.97 & 0.98 & 1.34 & - \\
\hline Thursday & 0.95 & 1.03 & 1.79 & 1.93 & 1.00 & + & 0.80 & 0.91 & 1.20 & 1.23 & 1.12 & - \\
\hline
\end{tabular}

Genotoxicity was determined by the IF of the neat sample (x1). Samples with IF $>1.5$ were considered as genotoxic and are represented in bold. [+] indicates positive for genotoxicity and [-] negative for genotoxicity.

bromocresol purple ( $2 \mathrm{mg} / \mathrm{ml})$. A $2.5 \mathrm{ml}$ volume from this mixture was added to $20 \mu \mathrm{l}$ from the bacterial culture and $17.5 \mathrm{ml}$ distilled water containing $0.2 \mathrm{ml}$ sample ( $1 \%$ sample concentration), $2 \mathrm{ml}$ sample (10\% sample concentration), $4 \mathrm{ml}$ sample (20\% sample concentration) and $10 \mathrm{ml}$ sample (50\% sample concentration). A volume of $200 \mu \mathrm{l}$ from this mixture was dispensed into 96 well microtitre plates. The plates were sealed in plastic bags and incubated at $37^{\circ} \mathrm{C}$ for 3 to 5 days. Negative (distilled water, DMSO) and positive controls (2-nitrofluorene: $50 \mathrm{ng} / \mathrm{ml}$ in fluctuation medium) were run concurrently [27]. The number of wells with color change was recorded. Yellow wells were considered as positive and purple wells were considered as negative. The sample is considered mutagenic if the number of the positive wells was significantly greater in treated plates than in the negative control plates. The Mutagenicity
Ratio MR is calculated by dividing the number of positive wells in treated plates by the number of positive wells in the negative control plates. These results were tested for significance by the Chi-square analysis by evaluating the treated plates versus the control plates [31].

\section{Results}

The induction factor (IF) values of the SOS chromotest of wastewater samples collected in February and August 2011 from a Lebanese University Hospital are summarized in (Tables 2 and 3 ) respectively. The samples were taken from 5 different pits, 2 times per day in the morning and in the afternoon during two 1-week (5 days) periods. The tester strain Escherichia coli PQ37 was exposed to different doses of the wastewater. Compounds were considered non genotoxic if the IF remains $<1.5$, as slightly genotoxic 
Table 3. Hospital Wastewater Genotoxicity as tested by the SOS chromotest from the second batch collected (August 19-25, 2011) at different concentrations.

\begin{tabular}{|c|c|c|c|c|c|c|c|c|c|c|c|c|}
\hline \multicolumn{13}{|c|}{ Pit 1} \\
\hline \multirow[t]{2}{*}{ Day } & \multicolumn{5}{|c|}{ Morning Sample Concentration } & \multirow{2}{*}{$\begin{array}{c}\text { Genotoxicity } \\
-\end{array}$} & \multicolumn{5}{|c|}{ Morning Sample Concentration } & \multirow{2}{*}{$\begin{array}{c}\text { Genotoxicity } \\
-\end{array}$} \\
\hline & $1 / 4$ & $1 / 2$ & $3 / 4$ & $\times 1$ & $\times 2$ & & $1 / 4$ & $1 / 2$ & $3 / 4$ & $\times 1$ & $\times 2$ & \\
\hline Friday & 5.39 & 5.68 & 6.03 & 7.07 & 11.16 & + & 4.13 & 4.51 & 4.48 & 4.96 & 6.96 & + \\
\hline Monday & 1.24 & 1.35 & 2.10 & 1.81 & 2.04 & + & 1.15 & 1.12 & 2.17 & 2.18 & 2.47 & + \\
\hline Tuesday & 2.76 & 3.17 & 3.72 & 3.97 & 4.38 & + & 3.47 & 4.17 & 4.30 & 4.51 & 4.95 & + \\
\hline Wed. & 2.71 & 3.54 & 3.70 & 3.84 & 3.92 & + & 1.78 & 2.86 & 3.96 & 4.04 & 4.40 & + \\
\hline Thursday & 2.15 & 2.49 & 2.79 & 2.80 & 3.10 & + & 1.23 & 1.57 & 1.60 & 2.38 & 2.82 & + \\
\hline \multicolumn{13}{|c|}{ Pit 2} \\
\hline & $1 / 4$ & $1 / 2$ & $3 / 4$ & $\times 1$ & $\times 2$ & - & $1 / 4$ & $1 / 2$ & $3 / 4$ & $\times 1$ & $\times 2$ & - \\
\hline Friday & 1.06 & 1.22 & 1.26 & 1.34 & 1.60 & - & 0.61 & 0.74 & 1.00 & 1.28 & 1.17 & - \\
\hline Monday & 0.72 & 0.80 & 0.88 & 0.94 & 1.30 & - & 0.95 & 1.04 & 1.09 & 1.24 & 1.58 & - \\
\hline Tuesday & 1.03 & 1.06 & 1.14 & 1.01 & 0.98 & - & 0.42 & 0.61 & 0.64 & 0.71 & 0.56 & - \\
\hline Wed. & 0.95 & 0.81 & 0.80 & 0.84 & 0.99 & - & 0.72 & 1.01 & 1.02 & 1.26 & 1.50 & - \\
\hline Thursday & 0.42 & 0.59 & 0.55 & 0.65 & 0.90 & - & 0.97 & 1.05 & 1.14 & 1.09 & 1.26 & - \\
\hline \multicolumn{13}{|c|}{ Pit 3} \\
\hline & $1 / 4$ & $1 / 2$ & $3 / 4$ & $\times 1$ & $\times 2$ & - & $1 / 4$ & $1 / 2$ & $3 / 4$ & $\times 1$ & $\times 2$ & - \\
\hline Friday & 0.65 & 0.68 & 0.71 & 0.81 & 0.77 & - & 0.74 & 0.75 & 0.78 & 1.01 & 0.95 & - \\
\hline Monday & 0.71 & 0.98 & 1.16 & 1.60 & 1.66 & + & 0.96 & 1.02 & 1.29 & 1.40 & 1.56 & - \\
\hline Tuesday & 0.71 & 0.78 & 0.79 & 1.03 & 0.64 & - & 0.42 & 0.49 & 0.61 & 0.70 & 0.69 & - \\
\hline Wed. & 1.14 & 1.16 & 1.19 & 1.39 & 1.62 & - & 1.06 & 1.37 & 1.34 & 1.67 & 1.33 & + \\
\hline Thursday & 1.64 & 1.68 & 1.69 & 3.96 & 2.74 & + & 2.66 & 2.76 & 3.04 & 3.65 & 3.01 & + \\
\hline \multicolumn{13}{|c|}{ Pit 4} \\
\hline & $1 / 4$ & $1 / 2$ & $3 / 4$ & $\times 1$ & $\times 2$ & - & $1 / 4$ & $1 / 2$ & $3 / 4$ & $\times 1$ & $\times 2$ & - \\
\hline Friday & 0.44 & 0.63 & 0.79 & 1.23 & 0.67 & - & 0.50 & 0.61 & 0.62 & 0.83 & 1.27 & - \\
\hline Monday & 0.77 & 0.92 & 0.99 & 1.60 & 1.05 & + & 0.65 & 0.70 & 0.68 & 0.81 & 1.13 & - \\
\hline Tuesday & 0.81 & 0.80 & 0.94 & 0.95 & 1.43 & - & 0.92 & 0.98 & 1.12 & 1.46 & 2.05 & - \\
\hline Wed. & 1.14 & 1.33 & 1.38 & 1.22 & 1.72 & - & 1.18 & 1.48 & 1.58 & 2.15 & 2.01 & + \\
\hline Thursday & 3.11 & 3.59 & 3.60 & 3.98 & 3.99 & + & 1.08 & 1.11 & 1.16 & 1.34 & 1.41 & - \\
\hline \multicolumn{13}{|c|}{ Pit 5} \\
\hline & $1 / 4$ & $1 / 2$ & $3 / 4$ & $\times 1$ & $\times 2$ & - & $1 / 4$ & $1 / 2$ & $3 / 4$ & $\times 1$ & $\times 2$ & - \\
\hline Friday & 0.42 & 0.43 & 0.60 & 1.21 & 1.60 & - & 1.16 & 1.04 & 1.25 & 2.01 & 2.24 & + \\
\hline Monday & 0.77 & 1.89 & 1.87 & 1.96 & 2.06 & + & 0.70 & 0.73 & 0.72 & 0.80 & 0.82 & - \\
\hline Tuesday & 0.86 & 0.98 & 1.06 & 1.70 & 2.08 & + & 1.92 & 2.16 & 2.15 & 2.34 & 2.51 & + \\
\hline Wed. & 2.19 & 2.52 & 2.72 & 3.18 & 3.24 & + & 1.98 & 2.41 & 3.11 & 3.07 & 3.16 & + \\
\hline Thursday & 2.10 & 2.13 & 2.76 & 2.94 & 3.04 & + & 1.78 & 2.32 & 2.56 & 3.36 & 2.97 & + \\
\hline
\end{tabular}

Genotoxicity was determined by the IF of the neat sample (x1). Samples with IF $>1.5$ were

considered as genotoxic and are represented in bold. [+] indicates positive for genotoxicity and [-] negative for genotoxicity.

if the IF ranges between 1.5 and 2, and as moderately or strongly genotoxic if the IF $>2$ [26]. The samples were tested as concentrated $(x 2)$, neat samples $(x 1)$, and $3 / 4^{\text {th }}, 1 / 2$ and $1 / 4^{\text {th }}$ sample diluted in medium. Negative controls consist of the solvent (distilled water or DMSO) and the culture medium; whereas 4-nitroquinoline 1-oxide (4NQO) was used as a positive control. Different concentrations of $4 \mathrm{NQO}$ were tested and $1 \mathrm{nmole}$ was adopted for the rest of the experiments (data not shown).

Out of a total of 100 samples of wastewater tested, 50 were positive with the SOS Chromotest. $25 \%$ were positive in the first batch in winter (Table 2) and $25 \%$ in the second batch in summer (Table 3). Pit 1 was the most genotoxic and all of its samples had an IF $>1.8$ at neat $(x 1)$ concentration.
Genotoxicity was dose dependent and it decreased at $75 \%$ dilution. Some samples required further dilution to remove genotoxicity. The strongest SOS response in Pit 1 was on Friday mornings. Pit 2 and pit 3 were in general not genotoxic as shown by the SOS chromotest (Tables 2 and 3 ). Some genotoxicity was observed in Thursday samples of Pit 3 in August. Pits 4 and 5 were non-genotoxic or exhibited marginal genotoxicity in February samples; whereas more genotoxicity was observed in August samples. Morning samples were more genotoxic than the afternoon samples except for Pit 5 in both batches and Pit 1 in summer.

The samples were further tested using the Ames fluctuation test to study if samples were mutagenic and able to induce a reverse mutation in the Salmonella TA98. Pit 
Table 4. Hospital Wastewater Genotoxicity as tested by the Ames fluctuation test from the first batch collected (February 22-28, 2011).

\begin{tabular}{|c|c|c|c|c|c|c|c|c|c|c|c|c|c|c|c|c|}
\hline & \multicolumn{4}{|c|}{ Pit 2 morning } & \multicolumn{4}{|c|}{ Pit 2 afternoon } & \multicolumn{4}{|c|}{ Pit 3 morning } & \multicolumn{4}{|c|}{ Pit 3 afternoon } \\
\hline & $1 \%$ & $10 \%$ & $20 \%$ & $50 \%$ & $1 \%$ & $10 \%$ & $20 \%$ & $50 \%$ & $1 \%$ & $10 \%$ & $20 \%$ & $50 \%$ & $1 \%$ & $10 \%$ & $20 \%$ & $50 \%$ \\
\hline Frid. & 1.00 & 1.25 & 1.50 & 1.75 & 0.75 & 1.00 & 1.50 & 1.50 & 2.50 & $3.00^{\mathrm{a}}$ & $3.25^{\mathrm{a}}$ & $3.25^{\mathrm{a}}$ & 0.75 & 1.00 & 1.75 & 1.75 \\
\hline Mon. & $4.50^{b}$ & $4.50^{b}$ & $4.75^{c}$ & $5.00^{c}$ & $3.75^{b}$ & $4.25^{b}$ & $4.75^{c}$ & $6.25^{c}$ & 2.00 & 2.25 & 2.25 & 2.50 & 1.25 & 1.50 & 2.25 & 2.25 \\
\hline Tues. & 0.78 & 0.78 & 0.89 & 1.00 & 0.67 & 0.67 & 0.78 & 0.78 & 2.00 & 2.50 & 3.00 & 4.00 & 1.00 & 2.00 & 3.20 & 3.20 \\
\hline Wed. & 0.75 & 1.00 & 1.25 & 1.75 & 0.50 & 1.50 & 2.00 & 2.00 & $5.50^{c}$ & $6.50^{c}$ & $7.00^{c}$ & $8.75^{c}$ & $6.00^{c}$ & $9.00^{c}$ & $9.33^{c}$ & $11.00^{c}$ \\
\hline \multirow[t]{3}{*}{ Thurs. } & 2.00 & $3.60^{\mathrm{b}}$ & $3.80^{\mathrm{b}}$ & $4.40^{\mathrm{c}}$ & 1.00 & 2.40 & $2.60^{\mathrm{a}}$ & $3.60^{\mathrm{b}}$ & 0.60 & 1.80 & $3.60^{b}$ & $4.00^{b}$ & 1.86 & $2.86^{b}$ & $3.57^{c}$ & $4.00^{c}$ \\
\hline & \multicolumn{4}{|c|}{ Pit 4 morning } & \multicolumn{4}{|c|}{ Pit 4 afternoon } & \multicolumn{4}{|c|}{ Pit 5 morning } & \multicolumn{4}{|c|}{ Pit 5 afternoon } \\
\hline & $1 \%$ & $10 \%$ & $20 \%$ & $50 \%$ & $1 \%$ & $10 \%$ & $20 \%$ & $50 \%$ & $1 \%$ & $10 \%$ & $20 \%$ & $50 \%$ & $1 \%$ & $10 \%$ & $20 \%$ & $50 \%$ \\
\hline Frid. & 1.40 & 1.60 & $3.20^{c}$ & $4.70^{c}$ & $2.20^{a}$ & $2.60^{b}$ & $2.70^{c}$ & $3.30^{c}$ & $5.10^{c}$ & $5.10^{c}$ & $6.00^{c}$ & $6.90^{c}$ & $4.50^{c}$ & $4.70^{c}$ & $7.00^{c}$ & $6.90^{c}$ \\
\hline Mon. & $2.50^{\mathrm{a}}$ & $3.00^{\mathrm{a}}$ & $3.00^{a}$ & $3.25^{\mathrm{a}}$ & 0.78 & 0.89 & 1.11 & 1.11 & $4.22^{c}$ & $5.00^{c}$ & $4.78^{c}$ & $8.33^{c}$ & $3.56^{c}$ & $3.89^{c}$ & $4.22^{\mathrm{c}}$ & $6.11^{c}$ \\
\hline Tues. & 0.50 & 2.00 & 2.00 & 3.00 & 0.00 & 1.50 & 2.00 & 2.00 & $20.00^{c}$ & $21.00^{c}$ & $20.50^{c}$ & $30.00^{c}$ & $17.50^{c}$ & $18.50^{c}$ & $20.00^{c}$ & $22.50^{c}$ \\
\hline Wed. & 3.00 & $4.00^{\mathrm{a}}$ & $3.33^{a}$ & $5.00^{b}$ & 2.00 & 2.67 & $3.33^{a}$ & $4.00^{\mathrm{a}}$ & $11.00^{c}$ & $12.33^{c}$ & $15.00^{c}$ & $17.33^{c}$ & $10.67^{c}$ & $11.00^{c}$ & $13.33^{\mathrm{c}}$ & $15.33^{\mathrm{c}}$ \\
\hline Thurs. & 0.86 & 1.14 & 1.29 & 2.86 & 0.43 & 1.14 & 1.29 & 1.29 & $6.86^{c}$ & $7.43^{c}$ & $9.86^{c}$ & $10.86^{c}$ & $5.71^{\mathrm{c}}$ & $6.00^{c}$ & $6.00^{c}$ & $6.86^{c}$ \\
\hline
\end{tabular}

The samples were tested at different concentrations $(1,10,20$, and 50\%). Mutagenicity Ratios were calculated and significance was evaluated by Chi-square analysis ( $\left.{ }^{\mathrm{a}} \mathrm{p}<0.05 ;{ }^{\mathrm{b}} \mathrm{p}<0.01 ;{ }^{\mathrm{c}} \mathrm{p}<0.001\right)$. Genotoxic samples are represented in bold.

Table 5. Hospital Wastewater Genotoxicity as tested by the Ames fluctuation test from the second batch collected (August 19-25, 2011).

\begin{tabular}{|c|c|c|c|c|c|c|c|c|c|c|c|c|c|c|c|c|}
\hline & \multicolumn{4}{|c|}{ Pit 2 morning } & \multicolumn{4}{|c|}{ Pit 2 afternoon } & \multicolumn{4}{|c|}{ Pit 3 morning } & \multicolumn{4}{|c|}{ Pit 3 afternoon } \\
\hline & $1 \%$ & $10 \%$ & $20 \%$ & $50 \%$ & $1 \%$ & $10 \%$ & $20 \%$ & $50 \%$ & $1 \%$ & $10 \%$ & $20 \%$ & $50 \%$ & $1 \%$ & $10 \%$ & $20 \%$ & $50 \%$ \\
\hline Frid. & 0.83 & 0.83 & 1.17 & 1.33 & 0.67 & 0.83 & 1.33 & 1.33 & $10.17^{c}$ & $11.67^{c}$ & $12.00^{c}$ & $12.00^{c}$ & $7.75^{c}$ & $8.62^{c}$ & $8.75^{c}$ & $11.12^{\mathrm{c}}$ \\
\hline Mon. & $2.22^{\mathrm{a}}$ & $2.44^{b}$ & $2.56^{b}$ & $2.56^{\mathrm{b}}$ & $2.11^{a}$ & $2.22^{\mathrm{a}}$ & $2.33^{a}$ & $2.44^{b}$ & $3.22^{c}$ & $3.44^{\mathrm{c}}$ & $4.22^{c}$ & $6.33^{c}$ & $4.22^{c}$ & $4.11^{c}$ & $5.11^{c}$ & $5.33^{c}$ \\
\hline Tues. & 0.50 & 1.50 & 1.75 & 1.75 & 0.75 & 1.00 & 1.25 & 1.25 & $8.33^{c}$ & $9.67^{\mathrm{c}}$ & $13.33^{\mathrm{c}}$ & $16.00^{c}$ & $7.33^{c}$ & $7.67^{c}$ & $9.33^{c}$ & $11.67^{c}$ \\
\hline Wed. & 2.00 & 3.20 & 4.20 & 4.40 & 0.60 & 1.00 & 1.40 & 1.20 & $6.80^{c}$ & $7.60^{c}$ & $8.40^{c}$ & $10.20^{c}$ & $6.00^{c}$ & $6.80^{c}$ & $8.20^{c}$ & $9.60^{c}$ \\
\hline \multirow[t]{3}{*}{ Thurs. } & 0.80 & 1.00 & 1.20 & 1.20 & 0.80 & 1.20 & 1.60 & 1.60 & $3.00^{\mathrm{a}}$ & $3.80^{c}$ & $5.60^{c}$ & $5.80^{c}$ & $2.80^{\mathrm{a}}$ & $4.40^{b}$ & $5.00^{c}$ & $5.20^{c}$ \\
\hline & \multicolumn{4}{|c|}{ Pit 4 morning } & \multicolumn{4}{|c|}{ Pit 4 afternoon } & \multicolumn{4}{|c|}{ Pit 5 morning } & \multicolumn{4}{|c|}{ Pit 5 afternoon } \\
\hline & $1 \%$ & $10 \%$ & $20 \%$ & $50 \%$ & $1 \%$ & $10 \%$ & $20 \%$ & $50 \%$ & $1 \%$ & $10 \%$ & $20 \%$ & $50 \%$ & $1 \%$ & $10 \%$ & $20 \%$ & $50 \%$ \\
\hline Frid. & $2.88^{b}$ & $3.62^{c}$ & $4.12^{\mathrm{c}}$ & $4.50^{c}$ & $2.50^{\mathrm{a}}$ & $3.12^{\mathrm{c}}$ & $3.75^{c}$ & $3.75^{c}$ & $6.38^{c}$ & $6.50^{c}$ & $6.50^{c}$ & $9.75^{c}$ & $5.00^{c}$ & $5.12^{\mathrm{c}}$ & $6.25^{c}$ & $8.75^{c}$ \\
\hline Mon. & 1.11 & 1.33 & 1.56 & 1.56 & 0.25 & 0.50 & 2.00 & 2.50 & $11.75^{c}$ & $14.00^{c}$ & $15.50^{c}$ & $20.00^{c}$ & $10.00^{c}$ & $10.00^{c}$ & $12.75^{\mathrm{c}}$ & $15.50^{c}$ \\
\hline Tues. & 2.33 & $3.67^{a}$ & $3.67^{a}$ & $4.00^{a}$ & 2.33 & 3.00 & $3.33^{\mathrm{a}}$ & $3.33^{a}$ & $13.33^{c}$ & $15.33^{c}$ & $17.67^{c}$ & $19.67^{\mathrm{c}}$ & $8.00^{c}$ & $8.80^{c}$ & $10.00^{c}$ & $10.60^{\mathrm{c}}$ \\
\hline Wed. & 2.00 & 2.20 & 2.20 & $3.40^{\mathrm{b}}$ & 1.80 & 2.40 & $2.60^{a}$ & $2.60^{a}$ & $5.20^{c}$ & $5.60^{c}$ & $7.00^{c}$ & $7.20^{c}$ & $5.40^{c}$ & $5.00^{c}$ & $6.40^{c}$ & $6.60^{c}$ \\
\hline Thurs. & 1.60 & $3.00 \mathrm{a}$ & $3.40^{b}$ & $3.40^{b}$ & 1.80 & 2.20 & $2.60^{a}$ & $3.20^{b}$ & $2.71^{b}$ & $3.00^{b}$ & $3.00^{b}$ & $3.71^{c}$ & 2.14 & $2.28^{a}$ & $2.86^{\mathrm{b}}$ & $3.00^{b}$ \\
\hline
\end{tabular}

The samples were tested at different concentrations $(1,10,20$, and 50\%). Mutagenicity Ratios were calculated and significance was evaluated by Chi-square analysis $\left({ }^{a} \mathrm{p}<0.05 ;{ }^{b} \mathrm{p}<0.01 ;{ }^{c} \mathrm{p}<0.001\right)$. Genotoxic samples are represented in bold.

1 was not tested with the Ames test since the high acidity interfered with the assay. The results of the samples from the first batch (Table 4) and second batch (Table 5) show that $67.5 \%$ of the tested samples were genotoxic. $60 \%$ of the samples were positive in the winter batch and $75 \%$ in the summer batch. Compounds were considered as mutagenic if the value of the Mutagenicity ratio (MR) was high enough and significant as evaluated by the chi-square analysis (Gilbert, 1980). These samples ranged from slightly, moderately to strongly genotoxic. The highest value of the MR was observed for Pit 5 Tuesday sample taken in February, in the morning ( $M R=20.00^{\circ}$, at $\left.1 \%\right)$.

As shown from the SOS and Ames test, the tested hospital wastewater samples were mostly genotoxic. The two sampling periods were characterized by a difference of the genotoxic response intensity. Higher IF and MR values were mostly detected in summer and not in winter samples. The two genotoxicity tests used in this study had different sensitivities. The SOS Chromotest allowed the detection of $50 \%$ of the samples as genotoxic (50 out of 100) whereas the Salmonella fluctuation test showed that $67.5 \%$ (54 out of 80 ) of the samples were genotoxic.

\section{Discussion}

To determine the genotoxicity of the wastewater of a University-Hospital in Lebanon, two complementary bacterial genotoxicity tests were performed. The SOS Chromotest and the Ames fluctuation test were applied on samples taken during February and August 2011. In general, these assays showed that 82 out of 100 hospital wastewater samples tested were genotoxic in at least one of the assays.

It is not easy to compare our results to those of other studies due to the variety of the composition of the hospitals wastewaters, the size and activity of the hospital, and the diversity of the genotoxic tests used. However, similar to other studies, many of the samples were genotoxic. According to Jolibois et al., [27], 55\% of the tested samples from Rouen University hospital wastewater were genotoxic as 
assayed by SOS Chromotest and the Salmonella fluctuation test. Later studies using a larger sample size indicate that $65 \%$ of the hospital wastewater was genotoxic [30]. StegerHartmann et al., [32] assayed genotoxicity in hospital sewage water using the umuC test and found that around $50 \%$ of the samples were genotoxic after activation with the S-9 liver extract. Hartmann et al., [33] found that $56 \%$ of the samples were genotoxic after assaying wastewater from a German hospital using the umuC test, the Salmonella test and the V79 chromosomal aberration test.

The two sampling periods showed different genotoxic intensity with the summer samples being in general more genotoxic than the winter samples (showing slightly higher IF and MR values). Jolibois et al., [27] obtained similar results and attributed the difference to the effect of increase of rain in winter. In this study, the influence of pluviometer could not be considered, because hospital wastewater and rain water are not mixed in the sewer of the hospital. The small difference in genotoxic intensity between different seasons may be due to a difference in hospital activity or due to higher temperatures in summer that may lead to evaporation of wastewater and concentration of genotoxins.

It must be emphasized that morning samples were more genotoxic than the afternoon samples except for Pit 5 (both batches) and Pit 1 (in summer batch). No real explanation can be given for this phenomenon. However, this may be attributed to the fact that most of the laboratory activities and operations take place in the morning or that the amount and the nature of chemicals and drugs disposed of in the morning differ from those in the afternoon. It could also be due to dilution of the chemicals during the day due to disposal of more waste. Thus, different dilutions were studied to suggest recommendations to the hospital to decrease or remove genotoxicity. The samples were tested at (x1) concentration, $75 \%$ of sample, $50 \%$ of sample, and $25 \%$ of sample diluted in medium. Genotoxicity was found to be dose-dependent. Further dilutions were also studied when the IF value was still $>1.5$ at $1 / 4^{\text {th }}$ dilution (data not shown). The samples were also tested at ( $x 2)$ concentration to increase the limit of detection of genotoxic samples; 58 out of 100 samples were positive instead of 50 with the SOS chromotest. However, the concentration of samples may cause the loss or modification of compounds [34] and hence the substantial loss of genotoxic activity [35].

The strongest SOS response was detected with pit 1 in a summer sample taken in the morning, with an induction factor equal to 11.164 (Table 3). The highest mutagenicity ratio was detected in pit 5 winter sample taken in the morning with a MR equal to 30 (Table 4). Pit 1 contains wastewater coming from the anatomypathology laboratory. The high genotoxic effect and even the carcinogenicity of chemicals (such as cytostatic agents and iodinated X-ray contrast media) present in these labs is confirmed [36]. Pit 5 contains sewage water from different departments (patient floors, doctors' clinics, emergency rooms, kitchen, dialysis, blood bank, laboratory, radiology). Studies showed that these effluents are loaded with patient excretions, pharmaceuticals, antibiotics (chloramphenicol, tetracycline and erythromycin), dyes, reagents, pathogenic microorganisms such as antibiotic resistant bacteria, bacterial flora, different viruses, and other products with mutagenic and cytotoxic acitivity [37]. The presence of considerable concentration of antibiotic such as fluoroquinolones and especially ciprofloxacin could cause high genotoxicity [38]. Due to the high concentration of antibiotics, resistant strains in pathogenic bacteria and multi-resistant microbial strains are formed in these effluents [39]. Genotoxins present in pit 5 induced both a back mutation in the Salmonella strain and an activation of the $E$. coli SOS repair system.

Many types of treatment have been applied to hospital wastewater worldwide, but studies showed that many of the chemicals present in this wastewater resist treatment and persist in the effluents of the water treatment plant. Chlorination, ozonation, biological oxidation, activated sludge, trickling, adsorption, biosorption, biological or chemical degradation, biotransformation and membrane bioreactors process are usually used in some wastewater treatment plants. Heavy metals, some antibiotics, cytostatic drugs, radioactive isotopes, lipid regulators and many other pharmaceuticals resist these treatments [40].

In Lebanon, treatment plants, if present, are either not operating or include only preliminary treatment operations that are inadequate to remove all the pollutants. In some hospitals, only dilution is applied. Dilution with uncontaminated wastewater could be a good way to reduce the direct effects of the toxins present in these effluents till proper disposal and treatment methods are set. In the studied hospital, dilution with wastewater coming from pit 2 used in the washing of mechanical equipment could be one way to reduce the genotoxic effects present in these effluents till an adequate treatment plant is ready. The membrane bioreactor process could be a solution to deal with hospital wastewater [41].

\section{Conclusion}

Due to the severity of the effect of hospital wastewater on the environment and on human health, hospitals must increase their effort to monitor and decrease the discharge of genotoxic chemicals. Proper legislative actions and precautionary measures need to be taken to avoid disposal of hospital wastewater loaded with genotoxins. There is a risk of a direct genotoxic effect on animal and plant life at the place of disposal and also an indirect effect due to the possibility of hospital wastewater reaching drinking water.

More work should be done in the analytical field to identify and quantify the main compounds responsible for the genotoxicity [42]. Further work is currently being done in an effort to backtrack the chemicals involved in the genotoxicity of the hospital wastewater tested in this study. 


\section{Competing interests}

The authors declare that they have no competing interests.

Authors' contributions

RAM was involved in the design, analysis of the work, and manuscript preparation. PAM was involved in conducting experimental procedures, data acquisition and compilation. CA was involved in the critical revision of the manuscript. ZD was involved in the design of the work especially the microbiological part and was involved in the critical revision of the manuscript. Final manuscript was read and approved by all the authors.

\section{Acknowledgement}

We thank the Lebanese National Research

Council for their financial support.

\section{Publication history}

EIC: Rob Harrison, University of Washington, USA.

Received: 10-Apr-2013 Revised: 06-May-2013

Accepted: 17-Jun-2013 Published: 24-Jun-2013

\section{References}

1. Kurelec B: The genotoxic disease syndrome. Mar. Environ. Res. 1993, 35:341-348. | Article

2. Quillardet $P$ and Hofnung $M$ : The SOS Chromotest, a colorimetric bacterial assay for genotoxins: procedures. Mutat Res 1985, 147:6578. | Article | PubMed

3. Zeiger $E$ : Mutagens that are not carcinogens: faulty theory or faulty tests? Mutat Res 2001, 492:29-38. | Article | PubMed

4. Holmbom B, Voss RH, Mortimer RD and Wong A: Fractionation, isolation and characterization of Ames-mutagenic compounds in kraft chlorination effluents. Environ Sci Technol 1984, 18:333-7. | Article I PubMed

5. Maruoka S, Yamanaka $S$ and Yamamoto Y: Isolation of mutagenic components by high-performance liquid chromatography from XAD extract of water from the Nishitakase River, Kyoto City, Japan. Sci Total Environ 1986, 57:29-38. | Article | PubMed

6. De Raat WK, Vink G J and Hanstveit AO: The significance of mutagenicity as a criterion in ecotoxicological evaluations. In: Waters MD, Daniels FB, Lewtas J, Moore MM, Nesnow S, Eds., Plenum Press: New York, Genetic Toxicology of Complex Mixtures1990, 249-269. | Book

7. Stahl RG, Jr.: The genetic toxicology of organic compounds in natural waters and wastewaters. Ecotoxicol Environ Saf 1991, 22:94-125. | Article | PubMed

8. Houk VS: The genotoxicity of industrial wastes and effluents. Mutat Res 1992, 277:91-138. | ArticleArticle | PubMed

9. Ho KTY and Quinn JG: Bioassay-directed fractionation of organic contaminants in estuarine sediment using the new mutagenic bioassay. Mutatox. Environ. Toxicol. Chem. 1993, 12:823-830. | Article

10. Balch GC, Metcalfe CD and Huestis SY: Identification of potential fish carcinogens in sediment from Hamilton Harbour, Ontario, Canada. Environ. Toxicol. Chem. 1995, 14:79-91. | Article

11. White PA, Rasmussen JB and Blaise C: Comparing the presence, potency, and potential hazard of genotoxins extracted from a broad range of industrial effluents. Environ Mol Mutagen 1996, 27:116-39. | Article | PubMed

12. Claxton LD, Houk VS and Hughes TJ: Genotoxicity of industrial wastes and effluents. Mutat Res 1998, 410:237-43. | Article | PubMed

13. Giuliani F, Koller T, Wurgler FE and Widmer RM: Detection of genotoxic activity in native hospital waste water by the umuC test. Mutat Res 1996, 368:49-57. | Article | PubMed

14. Kummerer K: Drugs in the environment: emission of drugs, diagnostic aids and disinfectants into wastewater by hospitals in relation to other sources--a review. Chemosphere 2001, 45:957-69. |

\section{Article I PubMed}

15. Hartmann A, Alder AC, Koller T and Widmer RM: Identification of fluoroquinolone antibiotics as the main source of umuC genotoxicity in native hospital wastewater. Environ. Toxicol. Chem. 1998, 17:377382. | Article |

16. Gautam AK, Kumar S and Sabumon PC: Preliminary study of physicochemical treatment options for hospital wastewater. J Environ Manage 2007, 83:298-306. | Article | PubMed

17. OSPAR Commission 2002 (156), ISBN 156 1-904426-02-6. Survey on Genotoxicity Test Methods for the Evaluation of Waste Water within Whole Effluent Assessment. I Website

18. Quillardet P, Huisman O, D'Ari R and Hofnung M: SOS chromotest, a direct assay of induction of an SOS function in Escherichia coli K-12 to measure genotoxicity. Proc Nat/ Acad Sci U S A 1982, 79:5971-5. | Article | PubMed Abstract | PubMed Full Text

19. Quillardet $P$, de Bellecombe $C$ and Hofnung $M$ : The SOS Chromotest, a colorimetric bacterial assay for genotoxins: validation study with 83 compounds. Mutat Res 1985, 147:79-95. | Article | PubMed

20. Hofnung $M$ and Quillardet $P$ : The SOS Chromotest, a colorimetric assay based on the primary cellular responses to genotoxic agents. Ann N Y Acad Sci 1988, 534:817-25. | Article | PubMed

21. Hubbard SA, Green MHL, Gatehouse D, Bridges J W: The fluctuation test in bacteria. In: Kilbey BJ, Legator M, Nichols W, Ramel C. Eds., Amsterdam, New York, Oxford: Elsevier Handbook of mutagenicity test procedures $1984,142-160$

22. Mortelmans $\mathrm{K}$ and Zeiger $\mathrm{E}$ : The Ames Salmonella/microsome mutagenicity assay. Mutat Res 2000, 455:29-60. | Article | PubMed

23. Ames BN, Lee FD and Durston WE: An improved bacterial test system for the detection and classification of mutagens and carcinogens. Proc Natl Acad Sci U S A 1973, 70:782-6. | Article | PubMed Abstract | PubMed Full Text

24. Wursch AT: Wastewaters: Occurrence of pharmaceutical substances and genotoxicity. Ph.D. Dissertation 2005, \#3280, Ecole Polytechnique Federale de Lausanne. I Pdf

25. Maron DM and Ames BN: Revised methods for the Salmonella mutagenicity test. Mutat Res 1983, 113:173-215. | Article | PubMed

26. Kevekordes S, Mersch-Sundermann V, Burghaus CM, Spielberger J, Schmeiser HH, Arlt VM and Dunkelberg H: SOS induction of selected naturally occurring substances in Escherichia coli (SOS chromotest). Mutat Res 1999, 445:81-91. | Article | PubMed

27. Jolibois B, Guerbet $M$ and Vassal S: Detection of hospital wastewater genotoxicity with the SOS chromotest and Ames fluctuation test. Chemosphere 2003, 51:539-43. | Article | PubMed

28. Miller JG: Living systems: the organization. Behav Sci 1972, 17:1-82. | Article I PubMed

29. Legault R, Blaise C, Rokosh D and Chong-Kit R: Comparative assessment of the SOS Chromotest kit and the Mutatox test with the Salmonella Plate Incorporation (Ames Test) and Fluctuation tests for screening genotoxic agents. Environmental Toxicology Water Qual. 1994, 9:45-57. | Article

30. Jolibois B and Guerbet M: Evaluation of industrial, hospital and domestic wastewater genotoxicity with the Salmonella fluctuation test and the SOS chromotest. Mutat Res 2005, 565:151-62. | Article I PubMed

31. Gilbert RI: The analysis of fluctuation tests. Mutat. Res.-Envir. Muta. 1980, 74:283-289. | Article

32. Steger-Hartmann T, Kummerer K and Hartmann A: Biological degradation of cyclophosphamide and its occurrence in sewage water. Ecotoxicol Environ Saf 1997, 36:174-9. | Article | PubMed

33. Hartmann A, Golet EM, Gartiser S, Alder AC, Koller T and Widmer RM: Primary DNA damage but not mutagenicity correlates with ciprofloxacin concentrations in German hospital wastewaters. Arch Environ Contam Toxicol 1999, 36:115-9. | Article | PubMed

34. Filipic M: Mutagenicity and toxicity of water extracts from the Sora river area. Mutat Res 1995, 342:1-8. | Article | PubMed

35. White PA, Rasmussen JB and Blaise C: Sorption of organic genotoxins 
to particulate matter in industrial effluents. Environ Mol Mutagen 1996, 27:140-51. | Article | PubMed

36. Kummerer K, al-Ahmad A and Mersch-Sundermann V:

Biodegradability of some antibiotics, elimination of the genotoxicity and affection of wastewater bacteria in a simple test. Chemosphere 2000, 40:701-10. | Article | PubMed

37. Fracasso ME, Barba A, Tessari G, Gasperini S and Brunello F: Urinary mutagenic activity after different immunosuppressive protocols in renal transplant patients. Mutat Res 1993, 319:279-83. | Article | PubMed

38. Giger W, Alder AC, Golet EM, Kohler HP, McArdell CS, Molnar E, Siegrist $\mathrm{H}$ and Suter J-FM: Occurrence and fate of antibiotics as trace contaminants in wastewaters, sewage sludges, and surface waters. Chimia 2003, 57:485-491. | Article

39. Loffler $D$ and Ternes TA: Analytical method for the determination of the aminoglycoside gentamicin in hospital wastewater via liquid chromatography-electrospray-tandem mass spectrometry. J Chromatogr A 2003, 1000:583-8. | Article | PubMed

40. Jones $\mathrm{OAH}$, Voulvoulis $\mathrm{N}$ and Lester JN: Human Pharmaceuticals in Wastewater Treatment. Processes. Crit. Rev. Environ. Sci. Technol. 2005, 35:401-427. | Article |

41. Kovalova L, Siegrist $H$, Singer $H$, Wittmer A and McArdell CS: Hospital wastewater treatment by membrane bioreactor: performance and efficiency for organic micropollutant elimination. Environ Sci Technol 2012, 46:1536-45. | Article | PubMed

42. Gupta P, Mathur N, Bhatnagar P, Nagar P and Srivastava S: Genotoxicity evaluation of hospital wastewaters. Ecotoxicol Environ Saf 2009, 72:1925-32. | Article | PubMed

\section{Citation:}

Abdel-Massih RM, Melki PN, Afif C and Daoud Z: Detection of genotoxicity in hospital wastewater of a developing country using SOS chromotest and Ames fluctuation test. J Environ Eng Ecol Sci 2013, 2:4.

http://dx.doi.org/10.7243/2050-1323-2-4 